\title{
The Oregon Child Absenteeism Due to Respiratory Disease Study (ORCHARDS):
}

\section{Rationale, Objectives, and Design}

Jonathan L. Temte ${ }^{1}$ MD, PhD, Shari Barlow ${ }^{1}$ BA, Maureen Goss ${ }^{1}$ MPH, Emily Temte ${ }^{1}$ BA, Amber

Schemmel ${ }^{1}$ BS, Bradley Maerz ${ }^{1}$ BS Cristalyne Bell ${ }^{1}$ BS, Lily Comp ${ }^{1}$ BA, Mitchell Arnold ${ }^{1}$ MPH, Kimberly

Breunig ${ }^{1}$ MPH, Sarah Clifford ${ }^{3}$ MPH, MS, Erik Reisdorf ${ }^{2}$ MS, Peter Shult ${ }^{2}$ PhD, Mary Wedig ${ }^{2}$ BS, Thomas

Haupt $^{3}$ MS, James Conway ${ }^{4}$ MD, Ronald Gangnon ${ }^{5} \mathrm{PhD}$, Ashley Fowlkes ${ }^{7} \mathrm{MPH}$, and Amra Uzicanin ${ }^{7} \mathrm{MD}$, $\mathrm{MPH}$

${ }^{1}$ Department of Family Medicine and Community Health, University of Wisconsin School of Medicine and Public Health. Madison, WI

${ }^{2}$ Wisconsin State Laboratory of Hygiene. Madison, WI

${ }^{3}$ Wisconsin Division of Public Health, Wisconsin Department of Health Services. Madison, WI

${ }^{4}$ Department of Pediatrics, Division of Infectious Diseases, University of Wisconsin School of Medicine and Public Health. Madison, WI

${ }^{5}$ Department of Biostatistics and Medical Informatics, University of Wisconsin School of Medicine and Public Health. Madison, WI

${ }^{6}$ Department of Population Health Sciences, University of Wisconsin School of Medicine and Public Health. Madison, WI

${ }^{7}$ US Centers for Disease Control and Prevention. Atlanta, GA 
medRxiv preprint doi: https://doi.org/10.1101/2021.02.01.21250878; this version posted February 4, 2021. The copyright holder for this preprint (which was not certified by peer review) is the author/funder, who has granted medRxiv a license to display the preprint in perpetuity.

It is made available under a CC-BY-NC-ND 4.0 International license .

\begin{abstract}
Background: Influenza viruses pose significant disease burdens through annual seasonal outbreaks and unpredictable pandemics. Existing influenza surveillance programs have relied heavily on reporting of medically attended influenza (MAI). Continuously monitoring cause-specific school absenteeism may identify local acceleration of seasonal influenza activity. The Oregon Child Absenteeism Due to Respiratory Disease Study (ORCHARDS; Oregon, WI) implements daily school-based monitoring of influenza-like illness-specific student absenteeism (a-ILI) in pre-kindergarten through grade 12 schools and assesses this approach for early detection of accelerated influenza and other respiratory pathogen transmission in schools and surrounding communities.
\end{abstract}

Methods: Starting in September 2014, ORCHARDS combined automated reporting of daily absenteeism within 6 schools and home visits to school children with acute respiratory infections (ARI). Demographic, epidemiological, and symptom data are collected along with respiratory specimens. Specimens are tested for influenza and other respiratory viruses. Household members can opt into a supplementary household transmission study. Community comparisons are possible using a pre-existing, long-standing, and highly effective influenza surveillance program, based on MAI at 5 primary care clinics in the same geographical area.

Results: Over the first 5 years, a-ILI occurred on 6,634 (0.20\%) of 3,260,461 student school days. Viral pathogens were detected in $64.5 \%$ of the 1,728 children with ARI who received a home visit. Influenza was the most commonly detected virus, noted in $23.3 \%$ of ill students. Influenza $(p<0.001)$ and adenovirus ( $\mathrm{P}=0.004)$ were significantly associated with a-ILI.

Conclusion: ORCHARDS uses a community-based design to detect influenza trends over multiple seasons and to evaluate the utility of absenteeism for early detection of accelerated influenza and other respiratory pathogen transmission in schools and surrounding communities. Initial findings suggest the study design is succeeding in collecting appropriate data to achieve study objectives. 
medRxiv preprint doi: https://doi.org/10.1101/2021.02.01.21250878; this version posted February 4, 2021. The copyright holder for this preprint (which was not certified by peer review) is the author/funder, who has granted medRxiv a license to display the preprint in perpetuity.

It is made available under a CC-BY-NC-ND 4.0 International license .

I. Background. Influenza viruses pose significant disease burdens through annual seasonal outbreaks and unpredictable pandemics. Seasonal outbreaks result in an average annual toll of nearly 12,000 to 61,000 deaths in the United States (1) and are associated with an estimated annual cost of $\$ 11.2$ billion.(2) While infrequent-only 4 have occurred since 1918-influenza pandemics are characterized by large numbers of cases and increased morbidity and mortality.(3) Interventions for seasonal and pandemic influenza include vaccines, antiviral medications, and nonpharmaceutical interventions (NPI), also known as community mitigation, but their combined success is predicated on timely deployment. NPI, the first line of defense (4), hinges on early detection and recognition of outbreaks.(4-6)

Existing influenza surveillance programs rely on ambulatory and inpatient medical facilities to report cases of influenza-like illness (ILI) and test-confirmed influenza. $(7,8)$ Even though influenza transmission among school-aged children frequently precedes subsequent community transmission $(9,10)$, there has been no effort to systematically evaluate whether school-based monitoring of influenza activity can complement routine surveillance or even serve as an early-warning system for increased influenza activity in schools and the wider community. Monitoring of school absenteeism is feasible, as seasonal outbreaks generally occur between late fall and early to mid-spring while schools are in session $(11,12)$, and most of the 13,588 school districts (13) across the United States routinely collect daily absenteeism data using electronic school information systems.(14)

Early evaluations have shown promise. During the 2009 influenza pandemic, there was high correlation ( $r=0.92)$ between hospitalized influenza cases and school absenteeism due to ILI.(15) This strong association, however, was likely due to the short and intense nature of the outbreak, which amplified absenteeism related to ILI. Conversely, monitoring all-cause absenteeism was less effective due to the "noise" associated with school data and the multi-factorial nature of absenteeism.(16-18) The value of 
medRxiv preprint doi: https://doi.org/10.1101/2021.02.01.21250878; this version posted February 4, 2021. The copyright holder for this preprint (which was not certified by peer review) is the author/funder, who has granted medRxiv a license to display the preprint in perpetuity.

It is made available under a CC-BY-NC-ND 4.0 International license .

continuously monitoring cause-specific absenteeism, such as ILI, over the entire school year to identify local activity acceleration of seasonal influenza is not well researched or understood.

II. ORCHARDS overview statement. The goal of Oregon Child Absenteeism Due to Respiratory Disease Study (ORCHARDS) is to develop and implement a system for daily school-based monitoring of ILIspecific student absenteeism in pre-kindergarten (4K) through grade 12 schools and assess the system's usability for early detection of accelerated influenza and other respiratory pathogen transmission in schools and surrounding communities. The theoretical relationships between influenza infection in school-aged children, K-12 absenteeism, and influenza infection in the surrounding community are demonstrated in Figure 1.

\section{Specific objectives and study hypotheses.}

\section{$\underline{\text { ORCHARDS objectives }}$}

- Develop an automated cause-specific school absentee monitoring system to identify school absences related to ILI in 4K-12 students across the selected school district on a daily basis (Figure 1; component 1).

- Determine the etiology of ILI in absent students (Figure 1; component 2).

- Detect within-household transmission of influenza in households from which a student has been absent from school due to ILI (Figure 1; component 3).

- Compare the data from ILI- and influenza-specific student absenteeism in the participating schools to data routinely collected in complementary influenza surveillance in the health care facilities serving the same general population of the school district (Figure 1; component 4).

Study hypotheses 
medRxiv preprint doi: https://doi.org/10.1101/2021.02.01.21250878; this version posted February 4, 2021. The copyright holder for this preprint (which was not certified by peer review) is the author/funder, who has granted medRxiv a license to display the preprint in perpetuity.

It is made available under a CC-BY-NC-ND 4.0 International license .

- There is a relationship between illness-specific absenteeism and influenza infection in the community (Figure 1; hypothesis 1).

- Influenza infection in school-aged children is related to absenteeism (Figure 1; hypothesis 2).

- Influenza infection in school-aged children is transmitted to household members (Figure 1; hypothesis 3).

\section{Methods.}

IVa. Location and timeframe.

Location: The Oregon School District (OSD: www.oregonsd.org) encompasses the villages of Oregon and Brooklyn, which are located in rural areas of Dane County, Wisconsin and span approximately 85 square miles (figure 2. Lat: $42.90 \mathrm{~N}$, Long: 89.43W; altitude: 1,053 feet).(19) The ORCHARDS team selected OSD based on school population size, familiarity, proximity to study resources, and coverage by an existing and successful MAI surveillance program. The region experiences distinct temperate seasonality with significant variations in temperature, precipitation, and humidity.

Community: The OSD population is estimated at 20,094 and is less racially and ethnically diverse, wealthier, and better educated than the average community in the United States (Table 1) (20). Ages of individual family members and mean household size are similar to the US average. The population is mainly distributed in the villages of Oregon $(10,390)$ and Brooklyn $(1,255)$ with the remainder in decentralized subdivisions and farms.

The OSD is comprised of 6 public schools with a growing enrollment, estimated at 4,091 students (19\% of total population) during the 2018-2019 school year.(21) There are 3 elementary schools (grade K-4)2 in Oregon and 1 in Brooklyn - with a combined 1,503 students. There is one intermediate school (grade 5-6) with 623 students and one middle school (grade 7-8) with 596 students, both located in 
medRxiv preprint doi: https://doi.org/10.1101/2021.02.01.21250878; this version posted February 4, 2021. The copyright holder for this preprint (which was not certified by peer review) is the author/funder, who has granted medRxiv a license to display the preprint in perpetuity.

It is made available under a CC-BY-NC-ND 4.0 International license .

Oregon. The high school (grade 9-12) has 1,145 students and is located in Oregon. There are 224 children enrolled in 4K programs.

Timeframe: Initiation of ORCHARDS data collection occurred in phases. Absenteeism data collection (objective 1) commenced at the beginning of the 2014-2015 academic year on September 2, 2014. Data collection from student home visits (objective 2) commenced January 5, 2015, immediately following the winter break. The household transmission sub-study (objective 3) started September 6, 2016. MAI surveillance (objective 4) has been ongoing since October 2009.(8) Whereas absenteeism data do not accrue during planned and unplanned school breaks-including summer and weekends-home visits with ill students and the household transmission study continue throughout the year. All components of ORCHARDS have continued without interruption until present.

\section{IVb. Absenteeism monitoring system.}

Reporting unscheduled absences: We introduced minimal modifications to an existing absenteeism reporting system. Parents report unscheduled absences to attendance staff using an automated telephone system. Callers are prompted to provide the student's name and the reason for absence, including symptoms if the child has a cold or flu-like illness. We worked with OSD to provide uniform messaging on each school's absentee line with additional information pertaining to influenza-like illness (ILI) symptoms:

"Please inform us if your child has any flu-like symptoms such as fever with cough, sneezing, chills, sore throat, body aches, fatigue, runny nose, and/or stuffy nose." In the event that a student is absent without a report, OSD attendance staff-in the interest of child safety-make repeated efforts to contact the home or parents/guardians before the end of the day. 
medRxiv preprint doi: https://doi.org/10.1101/2021.02.01.21250878; this version posted February 4, 2021. The copyright holder for this preprint (which was not certified by peer review) is the author/funder, who has granted medRxiv a license to display the preprint in perpetuity.

It is made available under a CC-BY-NC-ND 4.0 International license .

Absenteeism definition: Because of variability among the OSD schools in terms of the number of class periods, from 2 to 10 per day, for which a child can be absent and for simplicity/generalizability of electronic data retrieval, if a student is absent part of a school day, we consider them absent for the entire day.

Types of absenteeism: All-cause or total absenteeism (a-TOT) is defined as an absence for any reason. Absence due to illness (a-I) is an absence due to any reported illness. Absence due to ILI (a-ILI) is a subset of a-I for which ILI symptoms are reported. These operational definitions likely underestimated a-I and a-ILI due to under-reporting by parents.

a-ILI definition: We considered established definitions for ILI.(22-23) For simplicity of recognition by nonmedical attendance staff members, we used a simplified version of the CDC standard definition. ILI for ORCHARDS is defined as the presence of fever and at least one respiratory tract symptom (cough, sore throat, nasal congestion, or runny nose). We selected these symptoms based on data from the Wisconsin component of the Influenza Incidence Surveillance Project (W-IISP).(8) Reported fever plus one or more of these symptoms, as compared to respiratory symptoms in the absence of fever, is associated with a 9-fold increase in underlying influenza infection in school-aged children presenting for primary medical care (Temte, unpublished).

Data system: OSD utilizes Infinite Campus ${ }^{\circledR}(24)$, a commercially available electronic student information system (SIS), to track student scheduling, enrollment, performance, and attendance. This system allows attendance staff to identify a student, select a period, and select a reason for absence from a modifiable, drop-down pick list. The OSD Information Technology (IT) staff added an option for "Absent due to influenza-like illness" (a-ILI); this required less than 5 minutes to enable. 
medRxiv preprint doi: https://doi.org/10.1101/2021.02.01.21250878; this version posted February 4, 2021. The copyright holder for this preprint (which was not certified by peer review) is the author/funder, who has granted medRxiv a license to display the preprint in perpetuity.

It is made available under a CC-BY-NC-ND 4.0 International license .

Data extraction and secure file transfer: OSD IT staff created an automated process within Infinite Campus $^{\circledR}$ to extract daily counts of absent individuals by school, grade, and absence type (a-TOT, a-I and a-ILI). The data contain no personal identifiers and are fully compliant with the Family Educational Rights and Privacy Act (FERPA: 20 U.S.C. § 1232g; 34 CFR Part 99).(25) The data are sent to a secure file transfer protocol (ftp) site at the University of Wisconsin Department of Family Medicine and Community Health. We track daily totals of absentee counts in each category. In addition, we calculate the average daily count for each week of the school year in each category. The data flow is illustrated in Figure 3.

School incentive: Each school receives $\$ 4,000$ per year to defray costs associated with IT support and effort by the attendance staff.

\section{IVc. Assessment of influenza and absenteeism in children through home visits.}

Contact and screening: To comply with FERPA, interested parents/guardians voluntarily call the study line to determine if their child qualifies for a home visit. Students are not required to be absent to participate and it is not necessary for school to be in session for home visits to occur. If a student meets the inclusion criteria, a 20-minute home visit occurs within 2 days of initial phone contact and within 7 days of symptom onset.

Inclusion criteria include:

(1) student attends, or is eligible to attend (e.g., home schooled), a school within the OSD

(2) student has an illness characterized by at least 2 of 6 acute respiratory infection (ARI)/ILI symptoms (nasal discharge; nasal congestion; sneezing; sore throat; cough; fever)

(3) student scores at least 2 points on the Jackson scale (26-28)

Exclusion criteria include: 
medRxiv preprint doi: https://doi.org/10.1101/2021.02.01.21250878; this version posted February 4, 2021. The copyright holder for this preprint (which was not certified by peer review) is the author/funder, who has granted medRxiv a license to display the preprint in perpetuity.

It is made available under a CC-BY-NC-ND 4.0 International license .

(1) household member listed on Wisconsin Department of Corrections Sex Offender Registry (http://offender.doc.state.wi.us/public/) [for the safety of field staff]

(2) illness onset more than 7 days before anticipated time of specimen collection

(3) anatomical defect for which nasal specimen collection is contraindicated

(4) student participated too recently ( $<7$ days during peak influenza period and $<30$ days during other times, as determined by medically-attended surveillance program)

At the end of the screening process for a student meeting study criteria, family members are invited to participate in an optional household influenza transmission sub-study. Participation is allowed even if individual members opt out or are unable to complete the entire study.

Inclusion criteria include:

1. individuals of any age/gender residing in the same household as ORCHARDS participant

2. fluent in English

3. able to provide appropriate consent/assent

\section{Exclusion criteria include:}

1. anatomical defect for which nasal sampling is contraindicated

2. household participated too recently ( $<7$ days during peak influenza period and $<30$ days during other times, as determined by medically-attended surveillance program)

Acquiring informed consent/assent: Research coordinators obtain written informed consent from parents/guardians and/or adult students, and assent from younger students using forms tailored to reading levels based on age. Consent allows assessment of immunization records through the Wisconsin Immunization Registry and advanced laboratory analyses of respiratory specimens. Participants can opt 
medRxiv preprint doi: https://doi.org/10.1101/2021.02.01.21250878; this version posted February 4, 2021. The copyright holder for this preprint (which was not certified by peer review) is the author/funder, who has granted medRxiv a license to display the preprint in perpetuity.

It is made available under a CC-BY-NC-ND 4.0 International license .

for study personnel to contact them about future research opportunities. The consent process changed on August 27, 2018 to allow recurrent visits throughout the full academic year.

Data collection: Demographic, epidemiologic, and symptom data (Table 2) are collected on an Acute Respiratory Infection and Influenza Surveillance Form. This form (Supplement 1) is based on an instrument used in clinical settings since 2009 as part of the Wisconsin component of the Influenza Incidence Surveillance Project (W-IISP).(8) Accordingly, the data collected are comparable to data from other surveillance systems.

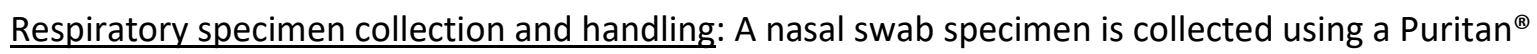
Sterile Foam Tipped Applicator for same-day rapid influenza diagnostic testing (RIDT). Starting on September 4, 2019, we started collecting the nasal specimen from both nostrils. In addition, a nasopharygeal (NP) or high oropharyngeal specimen (OP) is obtained using a Copan FLOQSwabs ${ }^{\mathrm{TM}}$ flocked swab. The NP/OP swab is placed into a $3.0 \mathrm{ml}$ Remel MicroTest ${ }^{\mathrm{TM}} \mathrm{M}^{\mathrm{M}} \mathrm{R} \mathrm{T}^{\circledR}$ Transport viral transport medium (VTM) tube, sealed and placed into a small resealable plastic biohazard bag, and maintained at $2-8^{\circ} \mathrm{C}$. Following processing for RIDT, the residual nasal swab is added to the VTM containing the NP/OP swab. A courier delivers the VTM tube to the Wisconsin State Laboratory of Hygiene (WSLH), usually within 24 hours of collection.

Incentives and feedback: Student participants receive a $\$ 20$ gift card at the end of the home visit. Research coordinators call parents/guardians with RIDT results within 24 hours (usually less than 4 hours) of the home visit. Laboratory confirmed results are mailed to families within 2 weeks of a home visit, and are accepted as documentation for an excused absence by the OSD. 
medRxiv preprint doi: https://doi.org/10.1101/2021.02.01.21250878; this version posted February 4, 2021. The copyright holder for this preprint (which was not certified by peer review) is the author/funder, who has granted medRxiv a license to display the preprint in perpetuity.

It is made available under a CC-BY-NC-ND 4.0 International license .

\section{IVd. Within-household influenza transmission sub-study.}

Contact and screening: At the ORCHARDS home visit, families expressing interest in the sub-study receive a packet containing sub-study information, instructions, consents/assents, and a small collection kit for each household member. The collection kit contains a data form, 2 nasal swabs, and 2 small

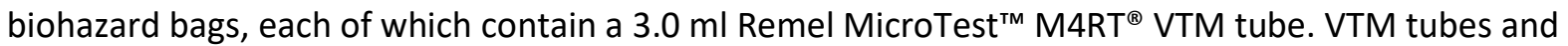
swabs for Day 0 and Day 7 are individually marked.

The research coordinator explains each component of the family packet to all household members who are present and reviews consent/assent forms. A designated adult assures that all interested household participants sign the consent/assent forms prior to specimen collection. Household members are responsible for collecting their own specimens on Day 0 (within 24 hours of home-visit) and Day 7 (seven days after the initial collection). The timing (Day 7) for follow-up data and specimen collection is based upon prior studies of household transmission of influenza.(29-31)

Data collection: The ORCHARDS Household Study Form (Supplement 2) is used to collect data pertaining to the following:

1. Household composition: the number and characteristics of people sharing the household of an ORCHARDS participant. Information includes relationship to the ORCHARDS participant, age, gender, number of bedrooms in home, employment outside of home, school attendance, and daycare attendance.

2. Household member illness assessment on Day 0 ("Today" section): influenza vaccine status for the current season, and information about any cold or flu-like illnesses occurring over the past 7 days (Table 3). 
medRxiv preprint doi: https://doi.org/10.1101/2021.02.01.21250878; this version posted February 4, 2021. The copyright holder for this preprint (which was not certified by peer review) is the author/funder, who has granted medRxiv a license to display the preprint in perpetuity.

It is made available under a CC-BY-NC-ND 4.0 International license .

3. Household member illness assessment on Day 7, one week after the initial visit ("Follow-up" section): information about any cold or flu-like illnesses occurring over the past 7 days (Table 3).

Respiratory specimen collection and handling: Research coordinators instruct household members on respiratory specimen collection from one nostril using a Copan FLOQSwabs ${ }^{\mathrm{TM}}$ flocked mid-turbinate swab (September 6, 2016 through October 15, 2017) or an anterior nasal Puritan ${ }^{\circledR}$ Sterile Foam Tipped Applicator (starting on October 16, 2017). On September 4, 2019, participants were instructed to swab both nostrils with a single swab. Each household participant collects the specimen without staff observation the day of the home visit (Day 0) and again seven days later (Day 7). Contact is made prior to or on Day 7 to reinforce completion of sub-study forms and specimens collection. When retrieving household collection kits, research coordinators review forms for completion and ensure specimens were collected and correspond with the appropriate labels.

Household incentive for participation: As an incentive for completing the household sub-study, participating families receive a $\$ 50$ gift card to local businesses when specimens are retrieved.

\section{IVe. Laboratory procedures.}

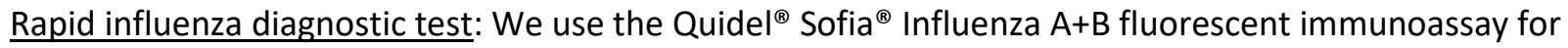
initial assessment of nasal specimens for ORCHARDS participants.(32) RIDT is performed at a nearby clinical facility within 6 hours of specimen collection following instructions outlined in the package insert. RIDT is not performed on specimens from household members.

Influenza rRT-PCR: All specimens from students and household members (Day 0 and Day 7) are tested at WSLH for influenza A and B virus and Human RNase P (RP) using the in-vitro diagnostic (IVD) FDA- 
medRxiv preprint doi: https://doi.org/10.1101/2021.02.01.21250878; this version posted February 4, 2021. The copyright holder for this preprint (which was not certified by peer review) is the author/funder, who has granted medRxiv a license to display the preprint in perpetuity.

It is made available under a CC-BY-NC-ND 4.0 International license .

approved CDC Human Influenza Virus Real-time RT-PCR Diagnostic Panel (Cat.\# FluiVD03) (33). Per protocol, the detection of RP, an indicator of human epithelial cells, with a cycle threshold (Ct) value $<38$ determines specimen adequacy for influenza PCR testing. Influenza A and B positive specimens are subtyped using the same testing kit.

Multipathogen testing: All specimens from ORCHARDS students are tested for influenza A, influenza B, rhinovirus/enterovirus, adenovirus, parainfluenza virus (1, 2, 3, 4), coronavirus (HKU1, NL63, 229E, OC43), respiratory syncytial virus (A, B), human metapneumovirus and human bocavirus, and 2 atypical bacterial pathogens, Chlamydia pneumoniae and Mycoplasma pneumoniae, using the multiplexed PCR respiratory pathogen panel (RPP: Luminex NxTAG Respiratory Pathogen Panel).(34)

Whole genome sequencing: For a subset of influenza-positive subjects, we conduct next-generation genome sequencing at the WSLH using the Illumina MiSeq ${ }^{\mathrm{TM}}$ platform. Sequence reads are trimmed using Trimmomatic with a 4 bp sliding window quality score cutoff of Q30.(35) The trimmed sequence reads are mapped against vaccine strain HA reference sequences using Geneious version 11.0.5.(36)

Quality control: The influenza rRT-PCR and multipathogen testing at the WSLH goes through a rigorous validation process to meet federal Clinical Laboratory Improvement Amendments licensing standards where sensitivity, reproducibility, accuracy and specificity have been demonstrated.

Specimen archiving: Aliquots of residual specimens, including all positive, negative, and nucleic acid are archived at $\leq-70^{\circ} \mathrm{C}$ at WSLH indefinitely or until CDC requests shipment. When requested, residual specimens and nucleic acid are submitted to CDC on dry ice by overnight shipment according to current practice and $C D C$ requests. 
medRxiv preprint doi: https://doi.org/10.1101/2021.02.01.21250878; this version posted February 4, 2021. The copyright holder for this preprint (which was not certified by peer review) is the author/funder, who has granted medRxiv a license to display the preprint in perpetuity.

It is made available under a CC-BY-NC-ND 4.0 International license .

IVf. Validation of influenza vaccination. We validate influenza immunization status for all ORCHARDS students using the Wisconsin Immunization Registry (WIR).(37) Students are determined to be fully vaccinated or not at the time of specimen collection using the guidance provided by the US Advisory Committee on Immunization Practices.(38) Subjects also provide consent to evaluate receipt status of other vaccines within WIR.

IVg. Data security and integrity. All identifying information on subjects is secured within UW Health using a separate password-protected security REDCap (Research Electronic Data Capture) database.(39) All other project data are kept in password-protected security-ensured REDCap databases. Data analysts are restricted to viewing outcome data, and are unable to access personal identifiers.

IVh. Community engagement and study promotion. The primary mode of ORCHARDS recruitment is the reminder within the absenteeism reporting system. Information is also provided at the OSD's unified registration each August and through e-mails to OSD families. We employ flyers, posters, and brochures at community sites, presentations at community events, mailings, postcards, the study website (www.fammed.wisc.edu/orchards/), and Facebook page (www.facebook.com/orchardstudy/). Moreover, the study team has extensive personal connections with the community through long-term residency within the OSD, children attending school in the district, and participation in school-based activities.

IVi. IRB and project oversight. All components of this proposed study were reviewed and approved by the Human Subjects Committees of the Education and Social/Behavioral Sciences IRB (initial approval on September 4, 2013) and the University of Wisconsin Health Sciences-IRB (initial approval on December 
medRxiv preprint doi: https://doi.org/10.1101/2021.02.01.21250878; this version posted February 4, 2021. The copyright holder for this preprint (which was not certified by peer review) is the author/funder, who has granted medRxiv a license to display the preprint in perpetuity.

It is made available under a CC-BY-NC-ND 4.0 International license .

5,2013 , with additional approvals as the protocol expanded and modified). The study is in full compliance with the Health Insurance Portability and Accountability Act of 1996 (HIPAA), FERPA, and all other federally mandated human subjects regulations. The US Office of Management and Budget has approved all forms used in this study.

IVg. Reference data: assessment of influenza in the surrounding community. A fully independent and long-standing influenza surveillance system is available to assess MAI in and around the OSD. W-IISP is sponsored by CDC and the Council of State and Territorial Epidemiologists and has conducted prospective, active surveillance for influenza and other respiratory viruses in medically attended patients with ARI or ILI since October $2009(8,40)$. The ORCHARDS research team organizes this surveillance system. Active surveillance occurs at 5 family practice clinics within or adjoining the OSD. Specific clinic locations include Belleville, Oregon, Madison (2 sites) and Verona (Figure 2). Together, the clinics recorded 412,752 ambulatory visits between June 29, 2014 and June 29, 2019 and assessed 4,069 individual ARI patients.

NP/OP swabs are collected from a subset of ambulatory patients with ARI and ILI. All specimens are tested at the WSLH for influenza A and B using the rRT-PCR (33) and, for other viruses, using a multiplexed PCR RPP.(34) Virological characterization is available for all $(n=4,069)$ individual patient visits.

\section{Results}

Va. Absenteeism data. Over the first 5 years of ORCHARDS, we have evaluated 3,260,461 student days (enrollment multiplied by school days). Total absenteeism accounted for 301,427 (9.2\%) of potential student days, a-I accounted for 58,126 (1.8\%) student days, and a-ILI accounted for 6,634 (0.2\%) student 
medRxiv preprint doi: https://doi.org/10.1101/2021.02.01.21250878; this version posted February 4, 2021. The copyright holder for this preprint (which was not certified by peer review) is the author/funder, who has granted medRxiv a license to display the preprint in perpetuity.

It is made available under a CC-BY-NC-ND 4.0 International license .

days. The daily counts for each type of absenteeism, showing the variability, are depicted in Figure 4.

The annual levels of absenteeism were similar across all 5 years (Table 4).

Vb. Home visits and basic virology. We completed 1,728 home visits for children with ARI. Children ranged in age from 4 to 18 years (mean \pm std.dev. $=9.9 \pm 2.5$ years). There were more male $(57 \%)$ than female (43\%) participants. Home visits occurred, on average, $56.3 \pm 46.5$ hours after onset of symptoms. The number of home visits per day were positively correlated with a-Tot $\left(r_{s}=0.20 ; p<0.001\right)$, a-I $\left(r_{s}=0.41\right.$; $p<0.001)$ and a-ILI $\left(r_{s}=0.40 ; p<0.001\right)$. Most children (79\%) reported school absenteeism due to the current illness episode.

Pathogens were detected in 1,115 (65\%) specimens; the majority (99\%) of these were viral. Codetections of viruses were noted in 66 students (6\% of individuals with virus detections). Influenza was the most commonly detected virus, noted in 402 (23\%) students, followed by rhinovirus/enterovirus. The numbers of viruses detected are provided in Table 5.

Vc. Validation of a-ILI definition. A simple, validated definition of influenza-like illness-related absence (a-ILI) is a prerequisite for monitoring. We used multivariate binary logistic regression to assess the relationships between pathogens and a-ILI within individual students while adjusting for age and sex. Cases for which no viruses were identified served as the reference set. Of the participating students evaluated between January 5, 2015 and June 30, 2019, 1,552 (90\%) with ARI onset while school was in session remained in the analysis. Influenza [FluA(H1), FluA(H3), FluB], and adenovirus (Ad) were significantly associated with positive likelihoods of being absent with an ILI; the presence of rhinovirus/enterovirus (R/E) was associated with a negative likelihood of a-ILI (Table 6). Other viruses were not associated with a-ILI. Accordingly, absence from school due to ILI using a simple definition 
medRxiv preprint doi: https://doi.org/10.1101/2021.02.01.21250878; this version posted February 4, 2021. The copyright holder for this preprint (which was not certified by peer review) is the author/funder, who has granted medRxiv a license to display the preprint in perpetuity.

It is made available under a CC-BY-NC-ND 4.0 International license .

(absent with fever and a respiratory symptom) is strongly associated with laboratory-confirmed influenza.

\section{Discussion.}

In contrast to routine national surveillance systems that rely on sentinel outpatient or inpatient data on medically attended cases of ILI, ORCHARDS uses a community-based design. It is well recognized that most cases of influenza do not present for medical attendance (40). Even less common are hospitalized cases of influenza and influenza-related mortality (41-42). It is also recognized that the attack rates of influenza are much higher in school-aged children than for any other demographic group (40), and that influenza has a significant contribution to school absenteeism.(43) Accordingly, ORCHARDS was designed to detect and evaluate-over multiple seasons-the temporal trends of influenza detection among the age group which is central to community-wide influenza transmission (school-aged children), and which may be less represented among MAl cases.

A number of studies evaluating absenteeism and influenza predate ORCHARDS $(15-18,44)$, but many have been limited by evaluating a single outbreak. Influenza does not follow a regular pattern in an area but rather encompasses outbreaks of variable magnitudes and temporal patterns due to differing influenza types, subtypes and clades $(45,46)$; this necessitates multiyear assessment of monitoring systems to assess generalizability. Moreover, influenza outbreaks can occur at any time over a fairly wide seasonal range (47), thus making assessments over several seasons necessary to evaluate for effects of timing. Finally, an observational approach allows accumulation of multiple periods of planned and unplanned (weather-related) school breaks that may allow evaluation of school closure for outbreak response. 
medRxiv preprint doi: https://doi.org/10.1101/2021.02.01.21250878; this version posted February 4, 2021. The copyright holder for this preprint (which was not certified by peer review) is the author/funder, who has granted medRxiv a license to display the preprint in perpetuity.

It is made available under a CC-BY-NC-ND 4.0 International license .

ORCHARDS takes advantage of a pre-existing, long-standing, and highly effective influenza surveillance system that has provided consistent evaluation of seasonal and pandemic influenza since October 2009 as a "gold standard" for daily comparability. This parallel system is based on MAI surveillance at 5 primary care clinics which overlap with the study catchment area and uses very similar data instruments and identical laboratory methods.

\section{Conclusions.}

The community involvement, longitudinal nature, and external comparability make ORCHARDS a unique study platform to evaluate the role of school-aged children on influenza transmission and the utility of cause-specific absenteeism monitoring for identifying influenza outbreaks. Initial findings suggest the study design is succeeding in collecting appropriate data to achieve study objectives. Early detection of influenza within a community is critical for public health mitigation and the reduction of overall disease burden. Additional studies are needed to determine the effect of school closure on influenza transmission.

\section{Abbreviations:}

4k: 4-year-old pre-kindergarten

a-I: absenteeism due to illness

a-ILI: absenteeism due to influenza-like illness

a-TOT: all-cause absenteeism

ARI: acute respiratory infection

CDC: Centers for Disease Control and Prevention

CoV: coefficient of variation

FERPA: Family Educational Rights and Privacy Act 
Flu: influenza

FDA: Food and Drug Administration

HIPPA: Health Insurance Portability and Accountability Act

ILI: influenza-like illness

IT: information technology

IRB: institutional review board

MAI: medically attended influenza

NP: nasopharyngeal

ORCHARDS: Oregon Child Absenteeism Due to Respiratory Disease Study

OSD: Oregon School District

OP: oropharyngeal

PCR: polymerase chain reaction

RIDT: rapid influenza diagnostic test

RedCap: Research Electronic Data Capture

RPP: respiratory pathogen panel

R/E: rhinovirus/enterovirus

RP: human RNAse $P$

SIS: school information system

W-IISP: Wisconsin Influenza Incidence Surveillance Project

WIR: Wisconsin Immunization Registry

WSLH: Wisconsin State Laboratory of Hygiene

VTM: viral transport medium 


\section{DECLARATIONS}

\section{Ethics approval and consent to participate}

All components of this proposed study were reviewed and approved by the Human Subjects

Committees of the Education and Social/Behavioral Sciences IRB (initial approval on September 4, 2013)

and the University of Wisconsin Health Sciences-IRB (initial approval on December 5, 2013, with

additional approvals as the protocol expanded and modified). The study is in full compliance with the Health Insurance Portability and Accountability Act of 1996 (HIPAA), FERPA, and all other federally mandated human subjects regulations. The US Office of Management and Budget has approved all forms used in this study.

\section{Availability of data and materials}

The datasets generated and/or analyzed during the current study are not publicly available because the study is ongoing, but may be available from the corresponding author on reasonable request.

\section{Competing interests}

Dr. Jonathan Temte has received financial and material support from Quidel Corporation. Dr. John Tamerius and Quidel Corporation have generously supplied RIDT analyzers and tests.

\section{Funding}

This study has been supported by CDC through the cooperative agreement \# 5U01CK000542-02-00. The findings and conclusions in this study are those of the authors and do not necessarily represent the official position of the Centers for Disease Control and Prevention. 
medRxiv preprint doi: https://doi.org/10.1101/2021.02.01.21250878; this version posted February 4, 2021. The copyright holder for this preprint (which was not certified by peer review) is the author/funder, who has granted medRxiv a license to display the preprint in perpetuity.

It is made available under a CC-BY-NC-ND 4.0 International license .

\section{Acknowledgements}

We are indebted to Dr. Brian Bussler and Dr. Leslie Bergstrom (former and current OSD

Superintendent), the OSD Board of Education, Mr. Jon Tanner (IT Director), and many individuals in the attendance and health offices for project facilitation, and to hundreds of students and their families within the OSD for enthusiastic participation in ORCHARDS. The Wisconsin State Lab of Hygiene provided excellent laboratory support and advice on best practices.

\section{References.}

1. CDC. Disease Burden of Influenza. Accessed 6/22/2020 at:

https://www.cdc.gov/flu/about/burden/index.html.

2. Putri WCWS, Muscatello DJ, Stockwell MS, Newall AT. Economic burden of seasonal influenza in the United States. Vaccine. 2018 Jun 22;36(27):3960-3966. doi: 10.1016/j.vaccine.2018.05.057. Epub 2018 May 22.

3. Monto AS, Fukuda K. Lessons from influenza pandemics of the last 100 years. Clin Infect Dis. 2019 Aug 17. pii: ciz803. doi: 10.1093/cid/ciz803.

4. Qualls N, Levitt A, Kanade N, Wright-Jegede N, Dopson S, Biggerstaff M, Reed C, Uzicanin A; CDC Community Mitigation Guidelines Work Group. Community mitigation guidelines to prevent pandemic influenza - United States, 2017. MMWR Recomm Rep. 2017 Apr 21;66(1):1-34. doi: 10.15585/mmwr.rr6601a1.

5. Lowe L, Dopson SA, Budd AP. Pandemic influenza readiness report on laboratory and epidemiology capacity-United States and territories, 2015. Health Secur. 2018 Jul/Aug;16(4):239-243. doi: 10.1089/hs.2018.0021. 
medRxiv preprint doi: https://doi.org/10.1101/2021.02.01.21250878; this version posted February 4, 2021. The copyright holder for this preprint (which was not certified by peer review) is the author/funder, who has granted medRxiv a license to display the preprint in perpetuity.

It is made available under a CC-BY-NC-ND 4.0 International license .

6. Meltzer MI, Gambhir M, Atkins CY, Swerdlow DL. Standardizing scenarios to assess the need to respond to an influenza pandemic. Clin Infect Dis. 2015 May 1;60 Suppl 1:S1-8. doi: 10.1093/cid/civ088.

7. CDC. Weekly U.S. Influenza Surveillance Report. Accessed 8/30/2019 at: https://www.cdc.gov/flu/weekly/index.htm.

8. Fowlkes A, Dasgupta S, Chao E, Lemmings J, Goodin K, Harris M, Martin K, Feist M, Wu W, Boulton R, Temte J, Brammer L, Finelli L. Estimating influenza incidence and rates of influenza-like illness in the outpatient setting. Influenza Other Respi Viruses. 2013: 7(5): 694-700.

9. Sasaki A, Hoen AG, Ozonoff A, et al. Evidence-based tool for triggering school closures during influenza outbreaks, Japan. EID. 2009;15:1841-1843.

10. Egger JR, Hoen AG, Brownstein JS, et al. Usefulness of school absenteeism data for predicting influenza outbreaks, United States. Letter to Editor. EID. Vol. 18, No. 8, August 2012.

11. Uscher-Pines L, Schwartz HL, Ahmed F, Zheteyeva Y, Meza E, Baker G, Uzicanin A. School practices to promote social distancing in K-12 schools: review of influenza pandemic policies and practices. BMC Public Health. 2018 Mar 27;18(1):406. doi: 10.1186/s12889-018-5302-3.

12. Temte JL, Meiman JG, Gangnon RE. School sessions are correlated with seasonal outbreaks of medically attended respiratory infections: electronic health record time series analysis, Wisconsin 2004-2011. Epidemiology and Infection Jan;147:e127. doi: $10.1017 / \mathrm{S} 0950268818003424$.

13. National Center for Education Statistics. Number of public school districts and public and private elementary and secondary schools: Selected years, 1869-70 through 2010-11. Accessed 10/20/2019 at: https://nces.ed.gov/programs/digest/d12/tables/dt12 098.asp.

14. Best K-12 Student Information Systems. Accessed 10/20/2019 at: https://www.g2.com/categories/k-12-student-information-systems. 
medRxiv preprint doi: https://doi.org/10.1101/2021.02.01.21250878; this version posted February 4, 2021. The copyright holder for this preprint (which was not certified by peer review) is the author/funder, who has granted medRxiv a license to display the preprint in perpetuity.

It is made available under a CC-BY-NC-ND 4.0 International license .

15. Williams NJ, Ghosh TS, Bisgard KM, Vogt RL. Comparison of 3 school-based influenza surveillance indicators: Lessons learned from 2009 pandemic influenza A (H1N1)-Denver Metropolitan Region, Colorado. J Public Health Manag Pract. 2013;19(2):119-25.

16. Besculides M, Heffernan R, Mostashari F, Weiss D. Evaluation of school absenteeism data for early outbreak detection, New York City. BMC Public Health. 2005;5:105.

17. Schmidt WP, Pebody R, Mangtani P. School absence data for influenza surveillance: a pilot study in the United Kingdom. Euro Surveill. 2010;15(3). pii: 19467.

18. Aldridge RW, Hayward AC, Field N, et al. Decipher my Data project and schools. Are school absences correlated with influenza surveillance data in England? Results from Decipher My Data-A Research Project conducted through Scientific Engagement with Schools. PLoS One. 2016;11(3):e0146964. doi: 10.1371/journal.pone.0146964.

19. Oregon School District. Accessed 10/20/2019 at: https://www.oregonsd.org/.

20. United States Census. Quick Facts. Accessed 10/20/2019 at: https://www.census.gov/quickfacts/oregonvillagewisconsin.

21. Wisconsin Department of Public Instruction. Wisconsin Information System for Education data Dashboard. Accessed 10/20/2019 at: https://wisedash.dpi.wi.gov/Dashboard/portalHome.jsp.

22. Thomas RE. Is influenza-like illness a useful concept and an appropriate test of influenza vaccine effectiveness? Vaccine. 2014 Apr 17;32(19):2143-9. doi: 10.1016/j.vaccine.2014.02.059.

23. Casalegno JS, Eibach D, Valette M, Enouf V, Daviaud I, Behillil S, Vabret A, Soulary JC, Benchaib M, Cohen JM, van der Werf S, Mosnier A, Lina B. Performance of influenza case definitions for influenza community surveillance: based on the French influenza surveillance network GROG, 2009-2014. Euro Surveill. 2017 Apr 6;22(14). pii: 30504. doi: 10.2807/15607917.ES.2017.22.14.30504.

24. Infinite Campus. Accessed 10/27/2017 at: https://www.infinitecampus.com. 
medRxiv preprint doi: https://doi.org/10.1101/2021.02.01.21250878; this version posted February 4, 2021. The copyright holder for this preprint (which was not certified by peer review) is the author/funder, who has granted medRxiv a license to display the preprint in perpetuity.

It is made available under a CC-BY-NC-ND 4.0 International license .

25. U.S. Department of Education. Family Educational Rights and Privacy Act (FERPA). Accessed 8/30/2019 at: https://www2.ed.gov/policy/gen/guid/fpco/ferpa/index.html.

26. Jackson GG, Dowling HF, Spiesman IG, Boand AV. Transmission of the common cold to volunteers under controlled conditions. Arch Intern Med. 1958;101:267-78.

27. Jackson GG, Dowling HF, Anderson TO, Riff L, Saporta J, Turck M. Susceptibility and immunity to common upper respiratory viral infections-the common cold. Annals of Internal Medicine 1960;55:719-38.

28. Jackson GG, Dowling HF, Muldoon RL. Present concepts of the common cold. Am J Public Health 1962;52:940-5.

29. Ng S, Lopez R, Kuan G, et al. The timeline of influenza virus shedding in children and adults in a household transmission study of influenza in Managua, Nicaragua. Pediatr Infect Dis J. 2016;35(5):583-6. doi: 10.1097/INF.0000000000001083.

30. Lau MS, Cowling BJ, Cook AR, Riley S. Inferring influenza dynamics and control in households. Proc Natl Acad Sci U S A. 2015 ;112(29):9094-9. doi: 10.1073/pnas.1423339112. Epub 2015 Jul 6.

31. Tsang TK, Lau LLH, Cauchemez S, Cowling BJ. Household Transmission of Influenza Virus Trends Microbiol. 2016 Feb;24(2):123-133. doi: 10.1016/j.tim.2015.10.012. Epub 2015 Nov 21.

32. Quidel. Sofia Influenza A+B FIA. Accessed 10/20/2019 at: https://www.quidel.com/immunoassays/rapid-influenza-tests/sofia-influenza-fia.

33. CDC (2011) CDC Human Influenza Virus Real-time RT-PCR Diagnostic Panel. Package Insert LB-029, R-

0.

34. Luminex. NxTAG ${ }^{\circledR}$ Respiratory Pathogen Panel. Accessed 10/20/2019 at:

https://www.luminexcorp.com/nxtag-respiratory-pathogen-panel/\#overview.

35. Bolger AM, Lohse M, Usadel B. Trimmomatic: A flexible trimmer for Illumina Sequence Data.

Bioinformatics. 2014;30:2114-20. 
medRxiv preprint doi: https://doi.org/10.1101/2021.02.01.21250878; this version posted February 4, 2021. The copyright holder for this preprint (which was not certified by peer review) is the author/funder, who has granted medRxiv a license to display the preprint in perpetuity.

It is made available under a CC-BY-NC-ND 4.0 International license .

36. Kearse M, Moir R, Wilson A, Stones-Havas S, Cheung M, Sturrock S, et al. Geneious Basic: an integrated and extendable desktop software platform for the organization and analysis of sequence data. Bioinformatics. 2012;28:1647-49.WGS

37. Wisconsin Department of Health Services. Wisconsin Immunization Registry. Accessed 10/20/2019 at: https://www.dhs.wisconsin.gov/immunization/wir.htm.

38. Grohskopf LA, Alyanak E, Broder KR, Walter EB, Fry AM, Jernigan DB. Prevention and Control of Seasonal Influenza with Vaccines: Recommendations of the Advisory Committee on Immunization Practices - United States, 2019-20 Influenza Season. MMWR Recomm Rep 2019;68(No. RR-3):1-21. DOI: http://dx.doi.org/10.15585/mmwr.rr6803a.

39. UW Institute for Clinical and Translational Research. REDCap. Accessed 10/20/2019 at: https://ictr.wisc.edu/redcap/.

40. Fowlkes A, Steffens A, Temte J et al; Influenza Incidence Surveillance Project Working Group. Incidence of medically attended influenza during pandemic and post-pandemic seasons through the Influenza Incidence Surveillance Project, 2009-13. Lancet Respir Med. 2015 Sep;3(9):709-18.

41. Rolfes MA, Foppa IM, Garg S, et al. Annual estimates of the burden of seasonal influenza in the United States: A tool for strengthening influenza surveillance and preparedness. Influenza Other Respir Viruses 2018; 12(1): 132-7.

42. Reed C, Chaves SS, Daily Kirley P, et al. Estimating influenza disease burden from population-based surveillance data in the United States. PLoS One. 2015; 10(3): e0118369.

43. McLean HQ, Peterson SH, King JP, Meece JK, Belongia EA. School absenteeism among school-aged children with medically attended acute viral respiratory illness during three influenza seasons, 2012-2013 through 2014-2015. Influenza Other Respir Viruses. 2017;11(3):220-229. doi:10.1111/irv.12440. 
medRxiv preprint doi: https://doi.org/10.1101/2021.02.01.21250878; this version posted February 4, 2021. The copyright holder for this preprint (which was not certified by peer review) is the author/funder, who has granted medRxiv a license to display the preprint in perpetuity. It is made available under a CC-BY-NC-ND 4.0 International license .

44. Cheng CK, Cowling BJ, Lau EH, Ho LM, Leung GM, Ip DK. Electronic school absenteeism monitoring and influenza surveillance, Hong Kong. Emerg Infect Dis. 2012;18(5):885-887. doi:10.3201/eid1805.111796.

45. Allena JD, Rossa TM. H3N2 influenza viruses in humans: Viral mechanisms, evolution, and evaluation. Hum Vaccin Immunother. 2018; 14(8): 1840-1847. doi:

10.1080/21645515.2018.1462639.

46. CDC. Types of Influenza Viruses. Accessed 10/20/2019 at: https://www.cdc.gov/flu/about/viruses/types.htm.

47. Bjørnstada ON, Viboudc C. Timing and periodicity of influenza epidemics. Proc Natl Acad Sci U S A. 2016 Nov 15; 113(46): 12899-12901. doi: 10.1073/pnas.1616052113. 
medRxiv preprint doi: https://doi.org/10.1101/2021.02.01.21250878; this version posted February 4, 2021. The copyright holder for this preprint (which was not certified by peer review) is the author/funder, who has granted medRxiv a license to display the preprint in perpetuity.

It is made available under a CC-BY-NC-ND 4.0 International license .

Table 1. Demographic descriptions of the Oregon School District (OSD) as compared to Dane County, Wisconsin, and the United States. Data from US Census.

\begin{tabular}{|c|c|c|c|c|}
\hline $\begin{array}{l}\text { Demographic } \\
\text { Feature }\end{array}$ & OSD & Dane County & Wisconsin & United States \\
\hline Total Population & 20,094 & 488,073 & $5,691,047$ & $312,700,151$ \\
\hline White $\left[\mathrm{nH}^{*}\right](\%)$ & 90.7 & 84.7 & 87.0 & 74.8 \\
\hline Black (\%) & 2.5 & 5.2 & 6.2 & 13.6 \\
\hline Am. Indian (\%) & 0.2 & 0.4 & 0.8 & 1.7 \\
\hline Asian (\%) & 1.9 & 4.7 & 2.3 & 5.6 \\
\hline Pacific Isl. (\%) & 0 & 0 & 0 & 0.4 \\
\hline Hispanic (\%) & 3.3 & 5.9 & 5.9 & 16.3 \\
\hline \multicolumn{5}{|l|}{ Ages } \\
\hline$<5$ years & 5.9 & 6.2 & 6.2 & 6.5 \\
\hline $5-19$ years & 21.3 & 18.7 & 17.2 & 20.4 \\
\hline $20-44$ years & 33.6 & 39.2 & 36.0 & 33.6 \\
\hline $45-84$ years & 30.3 & 25.7 & 27.7 & 26.4 \\
\hline $65^{*}$ years & 8.9 & 10.4 & 13.7 & 13.0 \\
\hline \multicolumn{5}{|l|}{ Household } \\
\hline Mean Size & 2.69 & 2.33 & 2.43 & 2.58 \\
\hline$<\$ 15,000$ & 4.4 & 10.9 & 6.1 & 13.4 \\
\hline$\$ 15,000-\$ 35,000$ & 10.5 & 18.6 & 33.1 & 22.3 \\
\hline$\$ 35,000-\$ 75,000$ & 33.0 & 32.0 & 46.0 & 32.5 \\
\hline$>\$ 75,000$ & 52.0 & 38.4 & 14.8 & 31.7 \\
\hline \multicolumn{5}{|l|}{ Education } \\
\hline$<$ High School & 4.1 & 2.1 & 9.9 & 14.4 \\
\hline High School/GED & 29.7 & 20.6 & 33.3 & 28.5 \\
\hline Some College & 30.3 & 27.0 & 30.5 & 28.9 \\
\hline Bachelor's & 24.6 & 28.1 & 17.4 & 17.7 \\
\hline Post BA/BS & 11.3 & 19.0 & 9.0 & 10.4 \\
\hline
\end{tabular}

$* \mathrm{nH}=$ non-Hispanic 
medRxiv preprint doi: https://doi.org/10.1101/2021.02.01.21250878; this version posted February 4, 2021. The copyright holder for this preprint (which was not certified by peer review) is the author/funder, who has granted medRxiv a license to display the preprint in perpetuity.

It is made available under a CC-BY-NC-ND 4.0 International license .

Table 2. ORCHARDS data elements obtained at all home visits. For details on data collection form, see supplement 1.

\begin{tabular}{|l|l|}
\hline Data Element & Description \\
\hline Epidemiological & Number of days from illness onset to home visit \\
\hline Time from symptom onset & Exposure to similar illness 1-3 days prior to illness onset \\
\hline Exposure to similar illness & Classmate, friend, family member, other \\
\hline Likely source & $\begin{array}{l}\text { Identification of all household members and presence of } \\
\text { similar illness }\end{array}$ \\
\hline Household members & Travel to destination $\geq 50$ miles in week before onset \\
\hline Recent travel & Contact with farm animals prior to illness onset \\
\hline Exposure to farm animals & \multicolumn{2}{|l|}{} \\
\hline Demographic & years \\
\hline Age & male / female / other \\
\hline Sex & Assigned school \\
\hline School & Standard categories \\
\hline Race & Standard categories \\
\hline Ethnicity & \multicolumn{2}{|l|}{} \\
\hline Clinical & Mild, moderate, severe as reported by parent/guardian \\
\hline Severity & Temperature taken by ORCHARDS staff at home visit \\
\hline Measured temperature & Presence/absence of 17 symptoms; other recorded \\
\hline Presence of symptoms & Reported by parent /guardian \\
\hline Use of antipyretics in last 6 hours & Reported by parent /guardian \\
\hline Recent influenza antiviral use & Reported by parent /guardian (verified through registry) \\
\hline $\begin{array}{l}\text { Receipt of current seasonal influenza } \\
\text { vaccine }\end{array}$ & Reported by parent /guardian \\
\hline Medical visit prior to home visit & Reported by parent /guardian \\
\hline Medical visit planned after home visit \\
\hline
\end{tabular}


medRxiv preprint doi: https://doi.org/10.1101/2021.02.01.21250878; this version posted February 4, 2021. The copyright holder for this preprint (which was not certified by peer review) is the author/funder, who has granted medRxiv a license to display the preprint in perpetuity.

It is made available under a CC-BY-NC-ND 4.0 International license .

Table 3. ORCHARDS household transmission study data elements obtained from all household participants. Some data elements are collected on Day $\mathbf{0}$ only, while other are collected on Day $\mathbf{0}$ and Day 7. For details on data collection form, see supplement 2.

\begin{tabular}{|l|l|c|c|}
\hline \multirow{2}{*}{ Data Element } & \multirow{2}{*}{ Description } & Response on \\
\cline { 3 - 4 } & & Day $\mathbf{0}$ & Day 7 \\
\hline Epidemiological & Measure of house size & \\
\hline Number of bedrooms in home & For adult household members (y/n) & $\mathrm{x}$ & \\
\hline Work outside of home & For school aged household members (y/n) & $\mathrm{x}$ & \\
\hline School attendance & For younger children (y/n) & $\mathrm{x}$ & \\
\hline Daycare attendance & Assessment for incidence of respiratory & $\mathrm{x}$ & $\mathrm{x}$ \\
\hline $\begin{array}{l}\text { Presence of respiratory illness or } \\
\text { symptoms in the past 7 days }\end{array}$ & infections (y/n) & $\mathrm{x}$ & $\mathrm{x}$ \\
\hline Time of onset of symptoms & Assessment of onset date & & \\
\hline Demographic & & $\mathrm{x}$ & \\
\hline Age & years & $\mathrm{x}$ & \\
\hline Gender & male / female / other & $\mathrm{x}$ & \\
\hline Relationship to ORCHARDS student & parent, guardian, sibling, grandparent, other & & \\
\hline Clinical & & $\mathrm{x}$ & $\mathrm{x}$ \\
\hline Severity of illness & $\begin{array}{l}\text { Mild, moderate, or severe as reported by } \\
\text { parent/guardian }\end{array}$ & $\mathrm{x}$ & $\mathrm{x}$ \\
\hline Presence of symptoms & Presence/absence of 10 symptoms & $\mathrm{x}$ & \\
\hline $\begin{array}{l}\text { Receipt of current seasonal } \\
\text { influenza vaccine }\end{array}$ & $\begin{array}{l}\text { Reported by parent /guardian (y/n) } \\
\text { (verified through immunization registry) }\end{array}$ & $\mathrm{x}$ & $\mathrm{x}$ \\
\hline Medical visit for this illness & Reported by parent /guardian (y/n) & $\mathrm{x}$ & $\mathrm{x}$ \\
\hline Venue of medical visit & Clinic, urgent care, emergency department & $\mathrm{x}$ & $\mathrm{x}$ \\
\hline Diagnosis from medical visit & Reported by parent /guardian & $\mathrm{x}$ & $\mathrm{x}$ \\
\hline Antibiotic or antiviral prescribed & Reported by parent /guardian & $\mathrm{x}$ & $\mathrm{x}$ \\
\hline Sent to hospital & Reported by parent /guardian (y/n) & $\mathrm{x}$ & $\mathrm{x}$ \\
\hline Absent from work/ school for illness & Number of absentee days (y/n) & $\mathrm{x}$ \\
\hline Number of days absent & Number of absentee days & $\mathrm{x}$ \\
\hline
\end{tabular}


medRxiv preprint doi: https://doi.org/10.1101/2021.02.01.21250878; this version posted February 4, 2021. The copyright holder for this preprint (which was not certified by peer review) is the author/funder, who has granted medRxiv a license to display the preprint in perpetuity.

It is made available under a CC-BY-NC-ND 4.0 International license .

Table 4. Enrollment estimates and absenteeism by defined type for the Oregon School District, Oregon, Wisconsin: 2014-2019.

\begin{tabular}{|l|c|c|c|c|c|}
\hline & $\mathbf{2 0 1 4 - 2 0 1 5}$ & $\mathbf{2 0 1 5 - 2 0 1 6}$ & $\mathbf{2 0 1 6 - 2 0 1 7}$ & $\mathbf{2 0 1 7 - 2 0 1 8}$ & $\mathbf{2 0 1 8 - 2 0 1 9}$ \\
\hline Total Estimated Enrollment* & 3,588 & 3,713 & 3,749 & 3,828 & 3,867 \\
\hline Total Curricular Days & 176 & 177 & 175 & 176 & 174 \\
\hline Total Possible Student Days & 629,024 & 635,076 & 649,775 & 673,728 & 672,858 \\
\hline a-TOT Days & 56,477 & 55,871 & 56,511 & 63,476 & 69,092 \\
(\% of total) & $(8.98 \%)$ & $(8.80 \%)$ & $(8.70 \%)$ & $(9.42 \%)$ & $(10.3 \%)$ \\
\hline Average Daily a-Tot & 320.9 & 315.7 & 322.9 & 360.7 & 397.1 \\
(std. dev.) & $(78.4)$ & $(79.2)$ & $(80.4)$ & $(96.3)$ & $(106.2)$ \\
\hline a-I Days & 12,024 & 12,158 & 11,922 & 11,710 & 10,312 \\
(\% of total) & $(1.91 \%)$ & $(1.91 \%)$ & $(1.83 \%)$ & $(1.74 \%)$ & $(1.53 \%)$ \\
\hline Average Daily a-I & 68.3 & 68.7 & 68.1 & 66.5 & 59.3 \\
std. dev.) & $(39.0)$ & $(27.0)$ & $(27.0)$ & $(30.1)$ & $(21.7)$ \\
\hline a-ILI Days & 1,314 & 1,609 & 1,309 & 1,261 & 1,141 \\
(\% of total) & $(0.21 \%)$ & $(0.25 \%)$ & $(0.20 \%)$ & $(0.19 \%)$ & $(0.17 \%)$ \\
\hline Average Daily a-ILI & 7.5 & 9.1 & 7.5 & 7.2 & 6.6 \\
(std. dev.) & $(7.3)$ & $(6.6)$ & $(5.9)$ & $(5.8)$ & $(5.5)$ \\
\hline
\end{tabular}

* Total estimated enrollment excluding 4K students (for whom absenteeism data is not submitted). Data extracted from: Wisconsin Department of Public Instruction, Wisconsin Information System for Education data Dashboard: https://wisedash.dpi.wi.gov/Dashboard/portalHome.jsp 
medRxiv preprint doi: https://doi.org/10.1101/2021.02.01.21250878; this version posted February 4, 2021. The copyright holder for this preprint (which was not certified by peer review) is the author/funder, who has granted medRxiv a license to display the preprint in perpetuity.

It is made available under a CC-BY-NC-ND 4.0 International license.

Table 5: Detections of viruses from ORCHARDS participants through home visits (January 5, 2015 to June 30, 2019). The counts include dual detections $(n=64)$ and triple detections $(n=2)$. Not shown are data for influenza A (unable to subtype: $n=3)$, Mycoplasma pneumoniae $(n=12)$, and Chlamydia pneumoniae $(n=1)$. Percentages are expressed as detections of specified virus groups divided by all detections.

\begin{tabular}{|c|c|c|c|c|c|c|c|c|c|}
\hline & \multicolumn{7}{|c|}{ Respiratory Virus Detected } \\
\cline { 2 - 11 } & Ad & CoV & FluA(H1) & FluA(H3) & FluB & hMPV & PIV & R/E & RSV \\
\hline $\begin{array}{c}\text { Number of } \\
\text { Detections }\end{array}$ & 32 & 169 & 77 & 224 & 98 & 74 & 77 & 368 & 47 \\
\hline Percent & 2.7 & 14.3 & 6.5 & 18.9 & 8.3 & 6.3 & 6.5 & 31.1 & 3.9 \\
\hline
\end{tabular}

$\mathbf{A d}=$ =adenovirus; $\mathbf{C o V}=$ coronavirus; Flu=influenza virus; RSV=respiratory syncytial virus; $\mathbf{h M P V = h u m a n}$ metapneumovirus; PIV=parainfluenza virus; $\mathbf{R} / \mathbf{E}=$ rhinovirus/enterovirus 
medRxiv preprint doi: https://doi.org/10.1101/2021.02.01.21250878; this version posted February 4, 2021. The copyright holder for this preprint (which was not certified by peer review) is the author/funder, who has granted medRxiv a license to display the preprint in perpetuity.

It is made available under a CC-BY-NC-ND 4.0 International license.

Table 6: Associations (odds ratios) of specific respiratory viruses with absences from school due to influenza-like illness (a-ILI) for K-12 children in the Oregon School District, Wisconsin, USA (January 5, 2015, to June 30, 2019).

\begin{tabular}{|c|c|c|c|c|c|c|c|c|c|}
\hline $\begin{array}{c}\text { Absenteeism } \\
\begin{array}{c}\text { Category } \\
\text { (Comparator) }\end{array}\end{array}$ & \multicolumn{7}{|c|}{ Respiratory Pathogen Detection Odds Ratio } \\
\cline { 2 - 11 } & Ad & CoV & FluA(H1) & FluA(H3) & FluB & hMPV & PIV & R/E & RSV \\
\hline number & 29 & 144 & 67 & 204 & 91 & 66 & 68 & 334 & 41 \\
\hline a-ILI & $\mathbf{3 . 8 0}$ & 0.86 & $\mathbf{1 2 . 0 1}$ & $\mathbf{3 . 6 5}$ & $\mathbf{5 . 1 5}$ & 1.44 & 1.56 & $\mathbf{0 . 6 3}$ & 0.89 \\
(Not a-ILI) & $(0.004)$ & n.s. & $(<0.001)$ & $(<0.001)$ & $(<0.001)$ & n.s. & n.s. & $(<0.001)$ & n.s. \\
\hline
\end{tabular}

$\mathbf{A d = a d e n o v i r u s ; ~ C o V = c o r o n a v i r u s ; ~} \mathbf{F l u = i n f l u e n z a ~ v i r u s ; ~} \mathbf{R S V}=$ respiratory syncytial virus; $\mathbf{h M P V = h u m a n}$ metapneumovirus; PIV=parainfluenza virus; $\mathbf{R} / \mathbf{E}=$ rhinovirus/enterovirus 


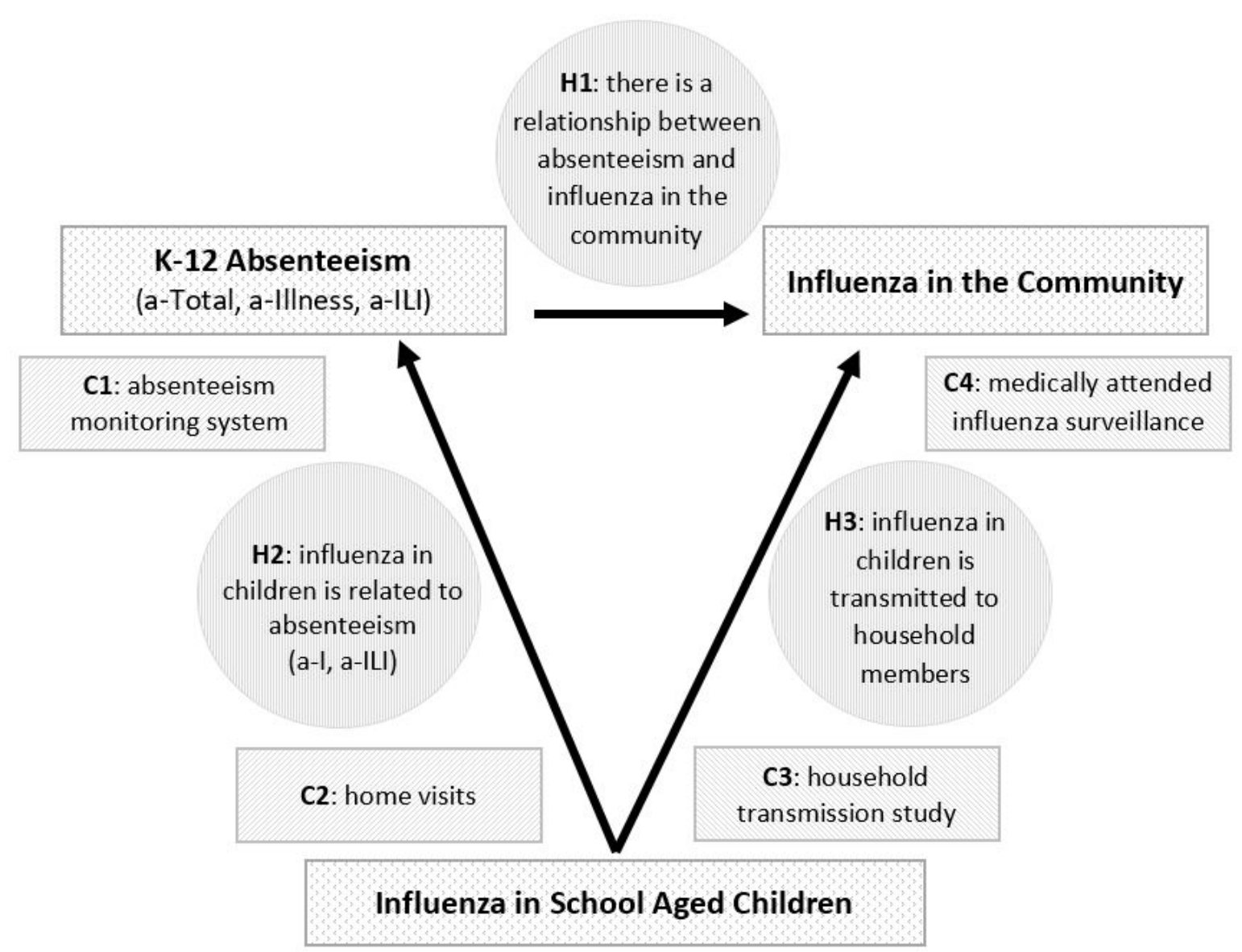

Figure 1. Theoretical framework of ORCHARDS demonstrating the relationships between influenza in school-aged children, $\mathrm{K}-12$ school absenteeism, and medically attended influenza in the community. The relatedness of the four components (C1-C4) of ORCHARDS and the three primary hypotheses (H1H3) are provided. 
medRxiv preprint doi: https://doi.org/10.1101/2021.02.01.21250878; this version posted February 4, 2021. The copyright holder for this preprint (which was not certified by peer review) is the author/funder, who has granted medRxiv a license to display the preprint in perpetuity.

It is made available under a CC-BY-NC-ND 4.0 International license .

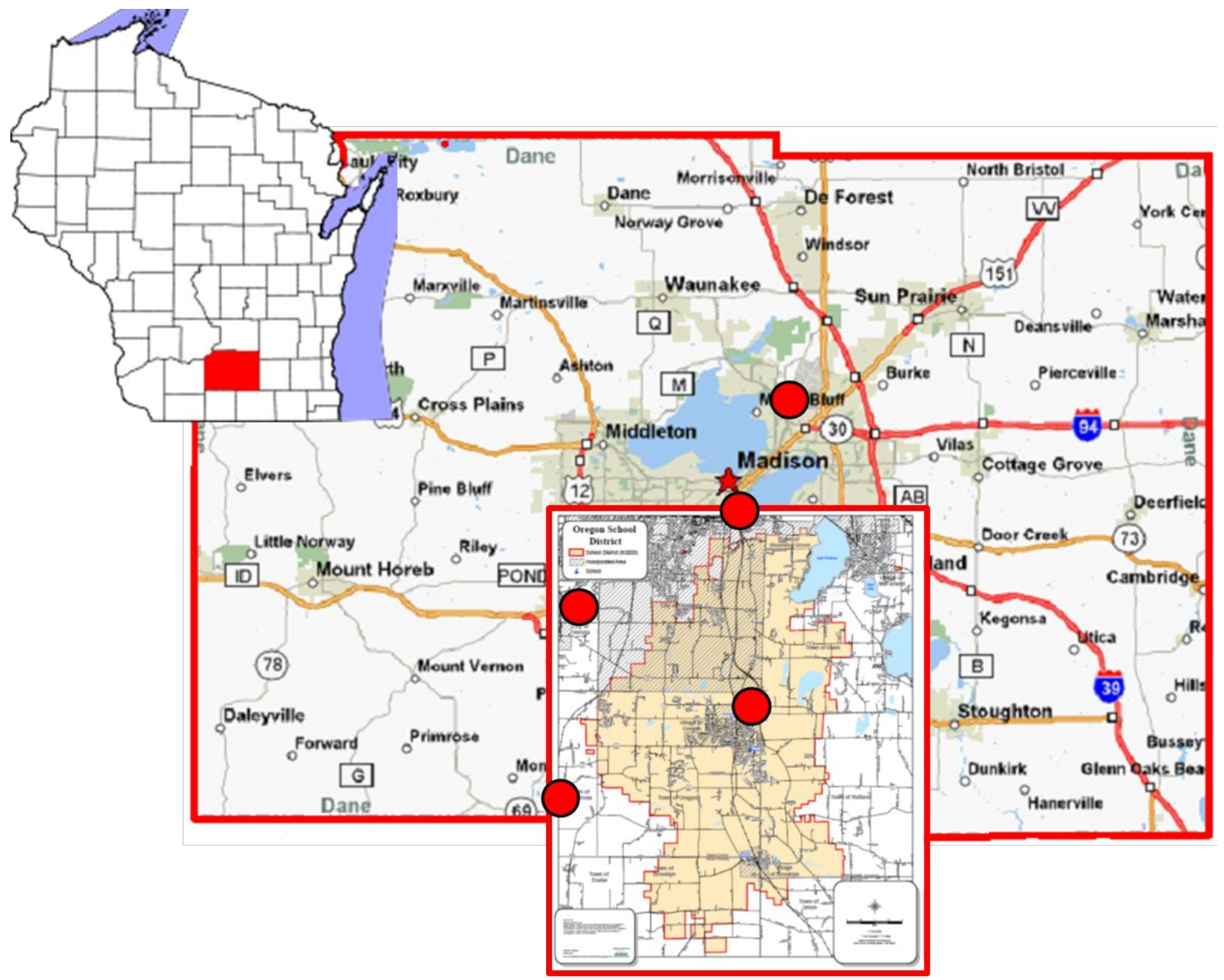

Figure 2. Location of the Oregon School District (OSD) in the Villages of Oregon and Brooklyn in southcentral Wisconsin. OSD extend past the southern border of Dane County and is drawn to scale.

The red dots indicate locations of family medicine clinics that have participated in long-term surveillance of medically attended influenza.

* Wisconsin state image created by David Benbennick Feb. 13, 2006. Image released to public domain:

https://en.wikipedia.org/wiki/Dane_County,_Wisconsin\#/media/File:Map_of_Wisconsin_highlighting_Dane_County.svg

† Dane County image was adapted from a Wisconsin Department of Transportation map that is licensed for non-commercial use and is in the public domain: http://lis202sec308.pbworks.com/w/page/91834941/Dane County\%2C

¥ The Oregon School District map was obtained from the district with permission to modify. The original graphic has been updated and is in the public domain: https://www.oregonsd.org/Page/5396 


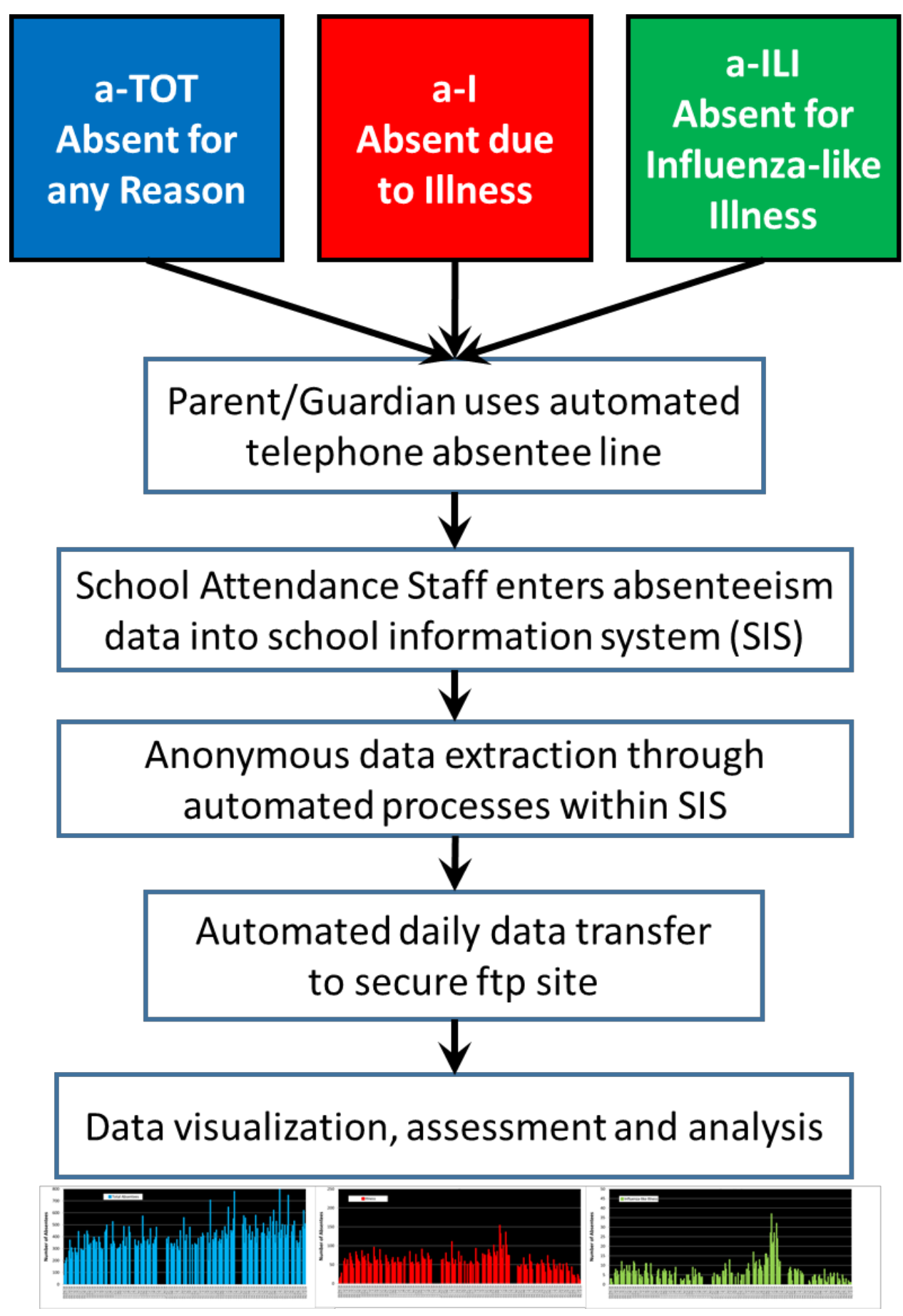

Figure 3. Flow diagram of absenteeism data from telephone reporting by parents/guardians, to entry into the student information system at the Oregon School District, to data transfer to the ORCHARDS research team. 
medRxiv preprint doi: https://doi.org/10.1101/2021.02.01.21250878; this version posted February 4, 2021. The copyright holder for this preprint (which was not certified by peer review) is the author/funder, who has granted medRxiv a license to display the preprint in perpetuity.

It is made available under a CC-BY-NC-ND 4.0 International license .

\section{a. Total Absentessism (a-TOT)}

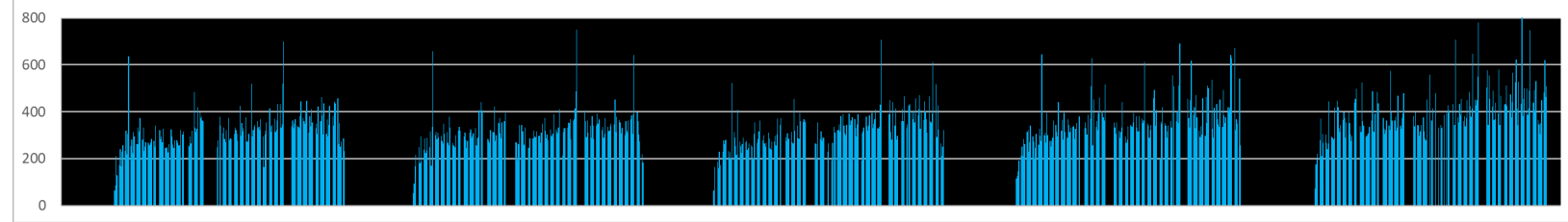

b. Illness Absentessism (a-I)

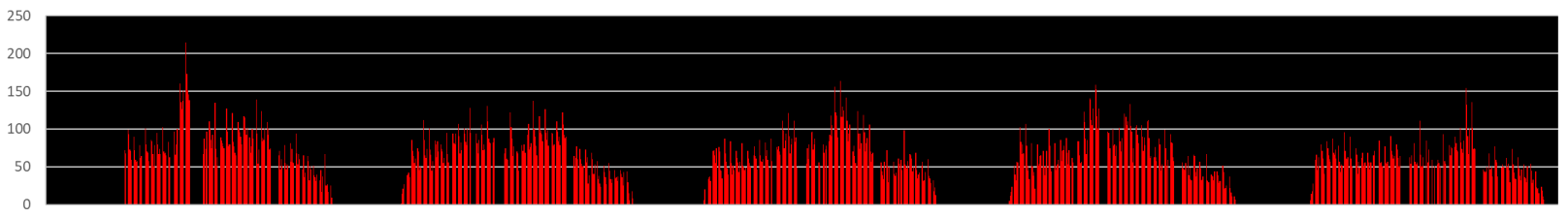

c. Influenza-Like IIIness Absentessism (a-ILI)

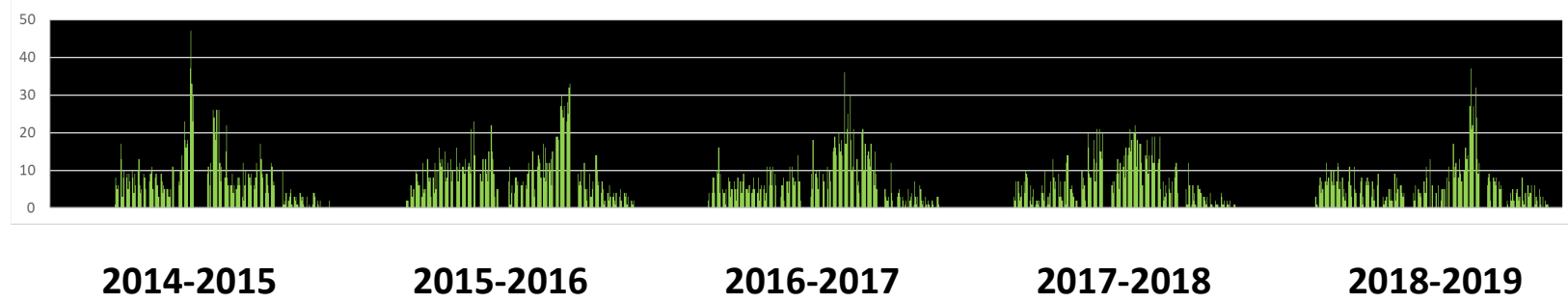

Figure 4. Daily counts of all absent students (a-TOT: panel a), students for whom an illness is reported

(a-I: panel b) and students absent with influenza-like illness (a-ILI: panel c) occurring over five consecutive school years at the Oregon school District, Wisconsin, USA from September 2014 through June 2019. 